\title{
PERNIKAHAN DINI WANITA YANG BERSATUS PEWARIS HARTA "TUNGGU TUBANG" (Studi Kasus Pada Masyarakat Suku Semendo Darat Ulu Kabupaten Muara Enim Sumatera Selatan)
}

\author{
Imam Mahdi* \\ Institut Agama Islam Negeri (IAIN) Bengkulu
}

Email: imam.mahdi@iainbengkulu.ac.id

\begin{abstract}
Early marriage in the Semendo tribe community, Muara Enim, South Sumatra is quite high, for women who hold the status of waiting for tubang, according to State law and religion is prohibited. Statistical data for the 2017 Semendo tribe population consisting of 3 subdistricts totaling 41,261 people and $100 \%$ are Muslim. Waiting for tubag is a customary term to refer to the oldest daughter in the family who will inherit the inheritance from their ancestors; The results of the study of early marriage, due to several factors, among others: female parents want to bequeath more quickly inherit assets waiting tubang, so that there are those who help in the physical work of managing inheritance, women who hold the waiting status intentionally their schools are limited to graduating from elementary / MI, because if the school is high enough, the parents are afraid that their children will not want to inherit assets such as their parents. Therefore, the Semendo tribe still applies the custom to match their daughters. Uniquely in this society, although many early marriage, divorce rarely occurs. This paper also shows that the practice of early marriage which is considered to cause a lot of problems such as violence, or exploitation of children and women does not occur. parents who marry off their young children, especially those who are waiting, will feel honored. This study recommends that the Government conduct interventions so that marital regulation and protection of children and women are carried out by involving religious and community leaders.
\end{abstract}

Keywords: Early Marriage, Wait Tubang, Society of Semendo

\begin{abstract}
Abstrak
Pernikahan usia dini pada masyarakat suku Semendo, Muara Enim Sumatera Selatan cukup Tinggi, bagi perempuan yang memegang status tunggu tubang, menurut hukum Negara dan agama dilarang. Data statistik tahun 2017 penduduk suku semendo yang terdiri dari 3 kecamatam berjumlah 41.261 jiwa dan $100 \%$ beragama Islam. Tunggu tubag adalah istilah adat untuk menyebutkan anak perempuan tertua dalam keluarga yang akan mewarisi harta kekayaan secara turun temurun dari nenek moyang mereka, memang harta tunggu tubang (harta tua) berupah rumah, sawah dan kebun tidak dibagi, menjadi hak penguasaan anak perempuan tertua. Hasil penelitian terjadinya pernikahan dini, dikarenakan beberapa faktor antara lain: orang tua wanita ingin lebih cepat mewariskan harta tunggu tubang, agar ada yang membantu dalam pekerjaan fisik pengurusan harta warisan, wanita yang memegang status tunggu tubang sengaja sekolahnya dibatasi hanya tamat SD/MI, karena kalau sekolah cukup tinggi orang tuanya takut anaknya tidak akan mau mewarisi harta tunggu tubang
\end{abstract}

${ }^{*}$ Dosen Program Studi Hukum Keluarga Islam (Akhwal Al-Syakhsiyah) Fakultas Syari'ah IAIN Bengkulu. 
seperti orang tua mereka. Oleh karena itu pada masyarakat suku Semendo masih berlaku kebiasaan untuk menjodohkan anak perempuan mereka. Uniknya pada masyarakat ini walaupun banyak perkawinan usia dini, jarang terjadi perceraian. Tulisan ini juga menunjukan bahwa praktik pernikahan usia dini yang dianggap akan banyak menimbulkan masalah seperti kekerasan, atau eksploitasi anak dan perempuan tidak terjadi. orang tua yang menikahkan anaknya yang masih berusia muda khususnya yang berstatus tunggu tubang akan merasa terhormat. Penelitian ini menyarankan kepada Pemerinta untuk mengadakan intervensi agar regulasi perkawinan dan perlindungan anak dan perempuan dilaksanakan dengan melibatkan tokoh agama dan tokoh masyarakat.

Kata Kunci: Pernikahan Dini, Tunggu Tubang, Masyrakat Semendo

\section{Pendahuluan}

Penelitian tentang pernikahan dini di Indonesia telah banyak dilakukan, tetapi fenomena budaya suatu daerah yang berkaitan langsung dengan pembagian waris adat seperti yang terjadi pada masyarakat Semendo Kabupaten Muara Enim Sumatera Selatan belum ditemukan oleh peneliti. Biasanya penelitian yang berkaitan dengan pernikahan dini di Indonesia berkaitan dengan tema yakni masalah ekonomi, kemiskinan, sosial budaya setempat sebagai salah satu fakor penyebab, seperti dikemukakan oleh Lies Marcoes direktur Rumah Kita Bersama mengemukakan bahwa kemiskinan struktural merupakan faktor terbesar yang menyebabkan terjadinya praktik perkawinan anak. ${ }^{1}$ Beban ekonomi pada keluarga sering kali mendorong orang tua untuk cepat-cepat menikahkan anaknya dengan harapan beban ekonomi keluarga akan berkurang, karena anak perempuan yang sudah nikah menjadi tanggung jawab suami. Hal ini banyak kita jumpai dipedesaan, tanpa peduli umur anaknya masih muda, apalagi kalau yang melamar dari pihak kaya, dengan harapan dapat meningkatkan derajatnya. ${ }^{2}$ Juga diteliti sebagai issu rendahnya tingkat pendidikan orang tua dan anak penyebab pernikahan dinia sebagaiman ditulis oleh Sunarto, ${ }^{3}$ Koalisi Perempuan Indonesia mengeluhkan masih banyaknya pernikahan terhadap anak. Tiap tahun, rata-rata ada 2 juta anak Indonesia yang melakukan pernikahan yang disebabkan karena tingkat pendidikan rendah dan kemiskinan. ${ }^{4}$

Memang di Indonesia pernikahan usia dini tergolong tinggi, berdasarkan data United Nations Children's Fund (UNICEF) memperkirakan bahwa satu dari

1 Lies Marcoes, Kemiskinan Struktural Adalah Faktor Terbesar Penyebab Praktek Perkawinan Anak, https://www.voaindonesia.com, diakses 28 Mei 2019.

2 Beteq Sardi, Faktor-faktor Pendorong Pernikahan Dini dan Dampaknya Di Desamahak Baru Kecamatan Sungai Boh Kabupaten Malinau, Journal, Sosiatri-Sosiologi 2016, 4(3): 194207ISSN 0000-0000, e-journal.sos.fisip-unmul.ac.id

3 Sunarto, 2007. Bahan Penyuluhan BKR Tentang Materi Ketahanan Keluarga Bagi Calon Pengantin. Jakarta: Badan Kependdudukan dan Keluarga Berencana Nasional $(\mathrm{BkkbN})$.

4 Dian Kartikasari, Penyebab Pernikahan Anak Karena Kemiskinan Dan PendidikanRendah, https://news.detik.com. Diakses 27 Mei 2019. 
enam anak perempuan di Indonesia menikah sebelum usia 18 tahun. Data Susenas pada tahun 2012 menunjukkan sebanyak 340.000 anak perempuan (17\%) telah kawin sebelum usia 18 tahun dari kelompok perempuan usia 20-24 tahun yang pernah kawin di Indonesia. ${ }^{5}$ Hampir separoh $(46,7 \%)$ dari kelompok perempuan usia 10-59 tahun yang berstatus menikah, telah menikah sebelum usia 20 tahun. ${ }^{6}$ Pada dasarnya Undang-Undang Perkawinan Indonesia sudah mengatur batas minimal usia perkawinan. Untuk perempuan batasnya 16 tahun dan laki-laki 19 tahun (Pasal 7 Ayat 1), namun batas usia ini tidak mampu dipegang teguh oleh Pengadilan Agama, sebagai institusi pemerintah yang berwenang, karena khususnya pada masyarakat Semendo lembaga adat masih sangat kuat sekali. Di tempat lain juga demikian seperti laporan dari Pengadilan Agama Kabupaten Madiun, Jawa Timur, memperlihatkan bahwa dalam tahun 2017 saja hampir 40 pasangan meminta dispensasi untuk menikah di bawah umur. $^{7}$

Indonesia memang tengah memasuki fase peralihan untuk pembangunan. Kondisi angka pernikahan anak yang tergolong masih sangat tinggi merupakan salah satu hal yang membuat negara "tertatih". Meskipun angka pernikahan anak mengalami penurunan secara bertahap dari 33\% pada 1985, 26\% pada 2010, dan $23 \%$ pada 2016 tapi prevalensinya masih tetap relatif konstan. ${ }^{8}$ Perkawinan usia dini pada masyarakat Semendo sebagai suatu budaya dan mempunyai motif tersendiri yakni untuk segera mewariskan harta tunggu tubang kepada anak gadis tertua sebagai pewaris tungggal dalam adat "tunggu Tubang" tersebut.

Pada masyarakat Semendo pernikahan usia dini tergolong tinggi berdasarkan data dari Kepala Kantor Urusan Agama (KUA) Kecamatan Semendo khususnya di tiga desa yang diteliti di Kecamatan Semendo Darat Ulu pada tahun 2017 tercatat 89 yang melangsungkan pernikahan, dari jumlah tersebut yang mengajukan despensasi pernikahan 46 pasangan dengan berbagai alasan, namun sebagaian besar dipastikan pengajuan dispensasi tersebut untuk melangsungkan pernikahan bagi anak perempuan pewaris tunggu tubang, sebagaimana dikatakan oleh TRM Kepala Desa Aremantai bahwa sebagain besar pernikahan dini yang terjadi di desanya adalah pasangan anak sebagai pewaris tunggu tubang, menurut TMR pada prinsipnya jika tidak bertentangan denga agama pihak pemerintah setempat akan memberikan rekomendasi untuk mengajukan dispensasi perkawinan kepada pihak yang berwenang. ${ }^{9}$

Persoalan ini juga didukung oleh pemahaman agama yang begitu kompleks di lingkungan masyarakat Semendo yang 100\% beragama Islam, dan

\footnotetext{
${ }^{5}$ Badan Pusat Statistik 2010, https://www.bps.go.id

${ }^{6}$ Riset Kesehatan Dasar, http://biofarmaka.ipb.ac.id.

7 Puluhan Permohonan Nikah dini di Madiun, https://www.antaranews.com

8 (https://news.detik.com/kolom/d-4044812/indonesia-masih-darurat-perkawinan-anak)

${ }^{9}$ Wawancara tanggal 23 Februari 2019.
} 
dalam agama Islam, menurut mereka tidak membatasi uisia perkawinan pada tingkat umur tapi pada tanda-tanda kedewasaan seoarang anak perempuan. ${ }^{10}$ Lies Marcoes, mengatakan perlu pula adanya perubahan pemahaman fiqih perkawinan. Selama ini masyarakat umumnya memandang praktek perkawinan anak dibenarkan oleh pandangan Fiqih perkawinan. Lies menilai, selama ini pemerintah telah lalai dan melakukan pembiaran atas praktek pernikahan anak ini. ${ }^{11}$

Oleh karena itu penelitian dewasa ini banyak menyoroti dampak negatif dari penikahan dini seperti baik tulisan lepas di media cetak dan on line maupun penelitian Edy Fdlyana dkk dengan judul Penikahan dini dan Permasalahannya, pada kesimpunanya menyebutkan bahwa Komplikasi psikososial akibat pernikahan dan kehamilan di usia dini didukung oleh suatu penelitian yang menunjukkan bahwa "keluaran negatif sosial jangka panjang yang tak terhindarkan, ibu yang mengandung di usia dini akan mengalami trauma berkepanjangan, selain juga mengalami krisis percaya diri". ${ }^{12}$ Kemudian Sarifah Salmah dalam tulisannya yang berjudul Pernikahan Dini Ditinjau Dari Sudut Pandang Sosial Dan Pendidikan, menyebutkan bahwa "Pernikahan merupakan suatu kegiatan yang yang merubah suatu hal yang haram menjadi halal dengan syarat sah sebuah pernikahan telah terpenuhi, tetapi yang menjadi fenomena di Indonesia, seperti di Kalimantan Selatan adalah tingginya angka pernikahan dini yang terjadi. Hal itu dikarenakan ada sebagian pemikiran dari masyarakat bahwa menikahkan anaknya dengan segera, maka dia tidak perlu lagi mengurus nafkah untuk anak tersebut, melepaskan tanggung jawabnya sebagai orang tua apa bila anaknya adalah perempuan. ${ }^{13}$ Penelitian lain seperti Juspin Landung, dengan judul Studi Kasus Kebiasaan Pernikahan Usia Dini Pada Masyarakat Kecamatan Sanggalangi Kabupaten Tana Toraja. ${ }^{14}$

Berbeda dengan penelitian diatas dank karena pada masyarakat semendo tergolong masyarakat yang cukup sejahtera menurut data statistik Kabupaten Muara Enim menujuknan bahwa tingkat kemiskinan Kabupaten Muara Enim pada kisaran 13, 19\% pada tahun 2017..5 Jadi dibawah rata-rata kemiskinan untuk daerah Kabupaten Muara Enim bahkan nasional.

Pembahasan dalam makalah ini akan difokuskan pada tiga persoalan, yakni Pertama, bagaimana praktik perkawinan anak di bawah umur berlangsung, khususnya di bagi anak tertua perempuan sebagai ahli waris Tunggu Tubang?

10 Wawancara tanggal 24 Februari 2019.

${ }^{11}$ Lies Marcoes, Kemiskinan Struktural....Op. Cit.

12 Eddy Fadlyana, Shinta Larasaty, Penikahan dini dan Permasalahannya, https://www.researchgate.net

13 Syarifah Salmah, Pernikahan Dini Ditinjau Dari Sudut Pandang Sosial Dan Pendidikan, Alhiwar Jurnal Ilmu dan Teknik Dakwah Vol. 04 No. 07 Januari-Juni 2016

14 Juspin Landung, Studi Kasus Kebiasaan Pernikahan Usia Dini Pada Masyarakat Kecamatan Sanggalangi Kabupaten Tana Toraa, Jurnal MKMI, Vol 5 No. 4, Oktober 200

${ }^{15}$ https://muaraenimkab.bps.go.id, diakses 23 April 2019. 
Kedua, Peran orang tua sebagai pewaris untuk menjodohkan anak gadis yang masih dibawah umum. Ketiga, bagaimana pandangan masyarakat Semendo terhadap kebiasaan yang terjadi diwilayah tersebut, berkaitan dengan pernikahan usia dini bagi anak gadis pewaris harta tunggu tubang?

\section{Metode Penelitian}

Tipe penelitian ini adalah penelitian deskrtiptif dengan pendekatan kualitatif yang dilakukan dengan tujuan menggambarkan atau mendeskripsikan obyek dan fenomena yang berkaitan dengan faktor-faktor yang menyebabkan terjadinya perkawinan usia dini pada masyarakat Kecamatan Semendo Darat Ulu Kabupaten Muara Enim, Penelitian dilakukan di tiga desa dari sepuluh desa dikecamatan Semendo Darat Ulu Kabupaten Muara Enim, yitu: Desa Pajar Bulan, Desa Aremantai dan Desa Segamit. Karena dari fakta yang ada dari tahun ke tahun jumlah remaja yang melakukan perkawinan di usia muda pada daerah tersebut tergolong cukup tinggi. Diantara mereka bahkan rela meninggalkan bangku sekolah untuk menikah diusia muda dengan salatu sebab utama untuk mewarisi harta Tunggu Tubang. Oleh karena itu teknik penentuan sampel yang akan penulis gunakan dalam penelitian ini adalah "Purposive Sampling". Yaitu penarikan sampel yang ditetapkan dengan sengaja oleh penulis, didasarkan atas beberapa kriteria khusus di ketiga desa tersebut. Alasan lainya karena desa tersebut merupakan desa dengan penduduk terbanyak di Kecamatan Semendo Darat Ulu Kabupaten Muara Enim. Di samping itu masyarakat di desa tersebut sangat familier dengan peneliti.

\section{Temuan}

Pernikahan bagi masyarakat Semendo khususnya yang berstatus tunggu tubang merupakan peristiwa adat yang terpenting, bahkan menempati urutan teratas dari serangkaian prosesi adat yang masih berlaku pada masyarakat tersebut, hal ini dimaklumi karena perkawinan itu akan melibatkan keluarga besar kedua belah pihak. Berdasarkan penelitian Yuni sartika menjelaskan bahwa:

"...untuk menikahi anak Tunggu Tubang hendaklah dengan syarat harus sanggup menikah secara meriah, dan jika Tunggu Tubang mempunyai harta pusaka lengkap juga calon suami harus memenuhi mahar nikah yang tidak kecil karena dilihat dari harta pusaka dari Tunggu Tubang itu sudah menjadi adat kebiasaan di Semende dan pemberian mahar itu hanya berlaku untuk anak tunggu tubang tidak termasuk dengan anak perempuan dibawahnya"16

Disamping sebagai peristiwa adat juga tidak lepas dari peristiwa agama yang sakral berdasrkan agama Islam yang dianut oleh masyarakat Semendo.

16 Yuni Sartika, Kadar Mahar Perkawinan Terhadap Anak Tunggu Tubang Di Kecamatan Semende Darat Kabupaten Muara Enim Ditinjau Dari Mazhab Syafi'i Dan Mazhab Hanafi, Skripsi, Fakultas Syari'ah UIN Raden Fatah Palembang, 2015, h. 13 
Bagi masyarakat Semendo keluarga Tunggu Tubang adalah sombol adat yang utama, pendapat umum mengatakan bahwa sebenarnya adat semendo tersebut tercermin dari adat tunggu tubang itu sendiri. "Menjadi tunggu tubang, dalam konsep dasar adat Semende merupakan sebuah kebanggaan tersendiri karena ia dipastikan akan dapat sawah, rumah, dan kebun. Persyaratan standar hidup di pedesaan sudah dipenuhinya. Seorang tunggu tubang akan berkuasa dalam mengelola harta yang ada. Oleh karena itu, memiliki sawah dapat menjadi pertanda bahwa seseorang itu sudah menjadi tunggu tubang atau bakal diwariskan. Di sinilah tampak bahwa sawah juga memiliki makna simbolis sebagai simbol kekuasaan dan posisi sosial seseorang. Di zaman dulu, terutama era sebelum 1990-an, seorang pria yang memperistrikan seorang tunggu tubang, dianggap punya prestasi tersendiri karena tidak mudah untuk mendapatkannya". ${ }^{17}$

Oleh karena itu biasanya orang Semendo dalam perkawinannya khususnya yang berstatus tunggu tubang jarang terjadi perceraian, disamping sudah mumpuni dalam status ekonomi juga perkawinan adalah peristiwa yang sangat disakralkan dan melibatkan klien besar masing-masing pihak, seperti terlihat dalam table dibawah ini menunjukkan bahwa pada tahun 2017 peristiwa perkawinan pada masyarakat Semendo sebagai berikut:

Tabel 1:

Jumlah Pasangan Nikah, Cerai Talak, Cerai Gugat dan Rujuk di Kecamatan Semendo Darat Ulu Tahun 2017

\begin{tabular}{|l|l|c|c|c|c|}
\hline \multirow{2}{*}{ No } & \multicolumn{1}{|c|}{ DESA } & \multicolumn{4}{|c|}{ Jumlah Pasangan } \\
\cline { 3 - 6 } & & Nikah & $\begin{array}{c}\text { Cerai } \\
\text { talak }\end{array}$ & $\begin{array}{c}\text { Cerai } \\
\text { Gugat }\end{array}$ & Rujuk \\
\hline $\mathbf{1}$ & Segamit & $\mathbf{2 3}$ & - & - & - \\
\hline 2 & Siring Agung & 6 & - & - & - \\
\hline $\mathbf{3}$ & Aremantai & $\mathbf{4 0}$ & - & - & - \\
\hline $\mathbf{4}$ & Pajar Bulan & $\mathbf{2 6}$ & - & - & - \\
\hline 5 & Tanjung Agung & 17 & - & - & - \\
\hline 6 & Datar Lebar & 11 & - & - & - \\
\hline 7 & Cahaya Alam & 26 & - & - & - \\
\hline 8 & Tanjung Tiga & 16 & - & - & - \\
\hline 9 & Pelakat & 4 & - & - & - \\
\hline 10 & Danau Gerak & 6 & - & - & - \\
\hline & Jumlah & $\mathbf{1 7 5}$ & - & - & - \\
\hline & Tahun 2016 & 165 & & & \\
\hline
\end{tabular}

Sumber: KUA Kecamtan Semendo Darat Ulu Tahun 2017

17 Yenrizal dkk. Makna Simbolik Sawah di Masyarakat Pedesaan Tinjauan Komunikasi Lingkungan pada Masyarakat Semende Darat Tengah, Jurnal Kawistara, Vol. 5, No. 3, Desember 2015 
Dari data tersebut menunjukkkan bahwa pada masyarakat Semendo Darat Ulu Tahun 2017 berjumlah 175 pasangan menikah, sebagai mana penelitian ini yang dikhususkan pada tiga desa yakni Desa Segamit sebanyak 23 pasang, desa Aremantai 40 pasang dan desa Pajar Bulan 26 pasang. Dari angka tersebut yang bersatus perempuan tunggu tubang berjumlah 61 pasang, di Desa Segamit 17 pasang, desa Aremantai 23 pasang dan desa Pajar Bulan 21 Pasang, selebihnya adalah pernikahan diluar status tunggu tubang yakni pernikahan janda dan pernikahan lainnya. Sedangkan usia menikah yang berstatus tunggu tubang dapat dilihat pada table dibawah ini:

Tabel 2:

Pasangan Usia Menikah pada masyarakat Semendo Darat Ulu

Dan menurut umur usia dibawah 16 bagi perempuan dan 19 tahun bagi laki-laki pada Tahun 2017.

\begin{tabular}{|c|c|c|c|c|c|c|}
\hline \multirow[t]{2}{*}{ No } & \multirow[t]{2}{*}{ DESA } & \multirow{2}{*}{$\begin{array}{l}\text { Jumlah } \\
\text { Nikah } \\
\text { (pasang) }\end{array}$} & \multicolumn{4}{|c|}{$\begin{array}{l}\text { Jumlah Pasangan menurut katagori pernikahan } \\
\text { dini }\end{array}$} \\
\hline & & & $\begin{array}{c}\text { Berstatus } \\
\text { Tuangu tubang }\end{array}$ & $\begin{array}{c}\text { Laki } \\
(<19 \mathrm{Th})\end{array}$ & $\begin{array}{l}\text { Perempuan } \\
(<16 \mathrm{Th})\end{array}$ & Ket. \\
\hline 1 & Segamit & 23 & 17 & 10 & 15 & - \\
\hline 2 & Siring Agung & 6 & 5 & 1 & 3 & - \\
\hline 3 & Aremantai & 40 & 23 & 7 & 15 & - \\
\hline 4 & Pajar Bulan & 26 & 21 & 5 & 13 & - \\
\hline 5 & Tanjung Agung & 17 & 14 & 10 & 11 & - \\
\hline 6 & Datar Lebar & 11 & 7 & 3 & 8 & - \\
\hline 7 & Cahaya Alam & 26 & 17 & 10 & 17 & - \\
\hline 8 & Tanjung Tiga & 16 & 15 & 11 & 12 & - \\
\hline 9 & Pelakat & 4 & 4 & 1 & 2 & - \\
\hline 10 & Danau Gerak & 6 & 5 & 2 & 3 & - \\
\hline & Jumlah & 175 & 128 & 60 & 99 & - \\
\hline & Tahun 2016 & 165 & & & & \\
\hline
\end{tabular}

Sumber: KUA Kecamtan Semendo Darat Ulu Tahun 2017 dan diolah sendiri.

Tabel diatas menunjukkan bahwa masih tingginya pasangan menikah pada usia muda bagi pasangan yang berstatus tunggu tubang seperti di desa Segamit ada 17 Pasang yang perempuan berusia dibawah 16 tahun sebanyak 15 orang dan laki-laki 10 orang, di Desa Aremantai dari 23 pasang pernikahan, 15 perempuan yang berusia dibawah 16 tahun dan dan laki-laki dibawah 19 tahun 7 orang serta di desa Pajar Bulan pasangan usia yang berstarus tunggu tubang yang menikah sebanyak 26 pasangan yang laki-laki berusia dibawah 19 tahun sebanyak 5 orang dan yang perempuan dibawah 16 sebanyak 13 orang. Dari tabel tersebut menunjukkan bahwa yang paling banyak menikah pada usia 
muda adalah perempuan dari 61 pasangan menikah dari tiga desa yang diteliti 43 orang permpuan dan yang laki-laki sebanyak 22 orang.

Jumlah penduduk Kecamatan Semendo Darat Ulu pada tahun 2017 dapat dilihat pada tabel berikut:

Tabel 3:

Jumlah penduduk, Perdesa di Kecamatan Semendo Darat Ulu Tahun 2017

\begin{tabular}{|l|l|c|c|c|c|}
\hline No & \multicolumn{1}{|c|}{ Nama desa } & $\begin{array}{c}\text { Jumlah } \\
\text { Penduduk } \\
\text { (jiwa) }\end{array}$ & $\begin{array}{c}\text { Laki- } \\
\text { laki }\end{array}$ & perempuan & $\begin{array}{c}\text { Rasio } \\
\text { Jenis } \\
\text { Kelamin }\end{array}$ \\
\hline $\mathbf{1}$ & Segamit & $\mathbf{3 . 1 3 6}$ & $\mathbf{1 . 5 6 8}$ & $\mathbf{1 . 5 6 8}$ & $\mathbf{1 0 0}$ \\
\hline 2 & Siring Agung & 636 & 327 & 309 & 105 \\
\hline $\mathbf{3}$ & Aremantai & $\mathbf{2 . 9 4 2}$ & $\mathbf{1 . 4 2 8}$ & $\mathbf{1 . 5 1 4}$ & $\mathbf{9 4}$ \\
\hline $\mathbf{4}$ & Pajar Bulan & $\mathbf{2 . 8 1 6}$ & $\mathbf{1 . 3 6 8}$ & $\mathbf{1 . 4 4 9}$ & $\mathbf{9 4}$ \\
\hline 5 & Tanjung Agung & 1.421 & 709 & 712 & 99 \\
\hline 6 & Datar Lebar & 943 & 490 & 474 & 103 \\
\hline 7 & Cahaya Alam & 2.077 & 1.045 & 1.032 & 101 \\
\hline 8 & Tanjung Tiga & 1.537 & 815 & 722 & 112 \\
\hline 9 & Pelakat & 685 & 353 & 332 & 106 \\
\hline 10 & Danau Gerak & 792 & 388 & 404 & 96 \\
\hline & Jumlah & $\mathbf{1 7 . 0 0 7}$ & $\mathbf{8 . 4 9 1}$ & $\mathbf{8 . 5 1 6}$ & $\mathbf{1 0 0}$ \\
\hline & & & & & \\
\hline
\end{tabular}

Sumber: BPS Kabupaten Muara Enim 2017

Dari tabel tersebut menujukan bahwa tiga desa yang diteliti yakni desa Segamit, desa Aremantai dan Desa Pajar Bulan merupakan desa yang penduduknya relatif lebih banyak dari desa-desa yang lain di Kecamatan Semendo Darat Ulu, dari penduduk sebanyak 17.007 jiwa tiga desa yang diteliti jumlahnya 8.894 Atau 50\% lebih.

Untuk melihat bahwa masyarakat Kecamatan Semendo darat Ulu, dari dulu samapai sekarang sebagai penganut agama Islam yang taat dapat dilihat dari tabel dibawah ini:

Tabel 3:

Jumlah Pemeluk Agama Perdesa di Kecamatan Semendo Darat Ulu Tahun 2017

\begin{tabular}{|c|c|c|c|c|c|c|}
\hline \multirow[t]{2}{*}{ No } & \multirow{2}{*}{$\begin{array}{c}\text { Nama } \\
\text { desa }\end{array}$} & \multicolumn{5}{|c|}{ Agama } \\
\hline & & Islam & $\begin{array}{c}\text { Kristen } \\
\text { Katholik/Protestan }\end{array}$ & Hindu & Budha & lainnya \\
\hline 1 & Segamit & 3.136 & - & - & - & - \\
\hline
\end{tabular}




\begin{tabular}{|l|l|r|c|c|c|c|}
\hline 2 & $\begin{array}{l}\text { Siring } \\
\text { Agung }\end{array}$ & 636 & - & - & - & - \\
\hline 3 & Aremantai & $\mathbf{2 . 9 4 2}$ & - & - & - & - \\
\hline $\mathbf{4}$ & $\begin{array}{l}\text { Pajar } \\
\text { Bulan }\end{array}$ & $\mathbf{2 . 8 1 6}$ & - & - & - & - \\
\hline 5 & $\begin{array}{l}\text { Tanjung } \\
\text { Agung }\end{array}$ & 1.421 & - & - & - & - \\
\hline 6 & $\begin{array}{l}\text { Datar } \\
\text { Lebar }\end{array}$ & 943 & - & - & - & - \\
\hline 7 & $\begin{array}{l}\text { Cahaya } \\
\text { Alam }\end{array}$ & 2.077 & - & - & - & - \\
\hline 8 & $\begin{array}{l}\text { Tanjung } \\
\text { Tiga }\end{array}$ & 1.537 & - & - & - & - \\
\hline 9 & Pelakat & 685 & - & - & - & - \\
\hline 10 & $\begin{array}{l}\text { Danau } \\
\text { Gerak }\end{array}$ & 792 & - & - & - & - \\
\hline & jumlah & 17.007 & - & - & - & - \\
\hline & & & - & - & - & - \\
\hline
\end{tabular}

Sumber: BPS Kabupaten Muara Enim 2017

Dari data tersebut menunjukan bahwa masyarakat Semendo yang tinggal di Kecamatan Semendo Darat Ulu 100\% beragama Islam, dan tidak ada perubahan sejak masyarakat tersebut mendiami daerah Semendo yang sudah ratusan tahun, sebagaiman dalam sejarahnya warga semendo tersebut telah ada sejak abad ke-17 sebagaimana dijelaskan oleh Iskandar dalam penelitiannnya sebagai berikut:

"bahwa suku Semendo Menurut Kohafah (Ketua Lembaga Adat Marga Semende Darat Laut), bahwa tanah Semende mulai dibuka pada tahun 1650M atau tahun $1072 \mathrm{H}$ oleh puyang yang bernama Syech Nurqadim al-Baharuddin. Dia lebih dikenal dengan sebutan Puyang Awak. Ditambahkan oleh Kohafah, bahwa Puyang Awak merupakan keturunan Sunan Gunung Jati melalui silsilah Puteri Sulung Panembahan Ratu Cirebon yang menikah dengan Ratu Agung Mpu Hyang Dade Abang. Beliau mewarisi ilmu kewalian dan kemujahidan Sunan Gunung Jati. Nurqadim dan ketiga adiknya dibesarkan oleh ayah ibunya di Istana Pelang Kedadai, yang terletak di Tanjung Lematang. Pada waktu kecilnya, beliau dididik akhlak al-karimah aqidah dan Islamiyah. Pada masa remajanya, beliau mendapat gemblengan para ulama dari Aceh Darussalam yang sengaja didatangkan ayahnya. ${ }^{18}$

${ }^{18}$ Iskandar, Kedudukan anak "Tunggu Tubang" dalam Kewarisan Masyarakat Adat Suku Semendo di Kota Palembang, Tesis Program Kenotaritan Universitas Diponegoro. Semarang, 2003, h. 31 Lihat Juga: Imam Mahdi, Konsep Gender Pada Masyarakat Adat Suku Semendo Kabupaten Muara Enim: Studi Kasus Pada Adat "Tunggu Tubang", Jurnal Hawa SPG IAIN Bengkulu Tahun 2019. 
Untuk lebih memperjelas data yang ada, peneliti melakukan wawancara mendalam informan di desa yang diteliti dengan ditentukan sebagai berikut: 1 informan aparat pemerintahan desa, 1 informan dari tokoh masyarakat/tokoh agama, 1 informan orang tua anak perempuan dan 3 orang perempuan dan 2 orang yang menikah dibawah umur yang bersatus tunggu tubang, jadi total informan dalam penelitian ini berjumlah 8 informan.

Informan 1 adalah seoarang perempuan pada saat menikah pada usia 13 tahun, informan baru tamat sekolah MI sejak usia sekolah telah membantu kedua orang tuanya dalam urusan rumah tangga. Orangtua informan mencarikan informan calon sumi untuk anaknya walaupun anak tersebut masih berusia muda dikarenakan orangtua informan ingin segera melepaskan tanggungjawab sebagai pemegang harta tunggu tubang. Calon suami informan masih ada hubungan saudara jauh dengan keluarga bapak informan. Calon suami informan tersebut usianya sudah dewasa yakni 23 tahun, suami informan yang sudah mapan, punya usaha sendiri yakni memeiliki kebun kopi pemberian orang tuanya. sehingga informan dapat membantu ekonomi keluarga informan setelah menikah nanti. Latar belakang keluarga informan yang ternyata juga menikah di usia muda. informan tidak menolak untuk dinikahkan kepada calon suaminya tersebut. Informan dan pasangannya sekarang sudah mempunyai 2 orang anak yang masih kecil dan tinggal bersama keluarga informan.

Informan 2 merupakan anak perempuan yang menikah pada usia 15 tahun, informan ini droup out SMP/MTs sejak duduk dibangku sekolah sudah membantu keluarga yakni mengurus adek-adek. Orang tua informan sudah lama mengenal suami calon suami informan, sehingga orang tua informan menyetujui informan menikah pada usia muda. Ekonomi suami informan tidak tergolong mamapan karena masih ikut sama orang tua, akan tetapi calon suami informan termasuk orang yang rajin bekerja dan tergolong pemuda yang alim, ini juga menjadi salah satu faktor mengapa orangtua informan menyetujui anaknya menikah di usia yang masih muda atas lamaran dari pihak keluarga calon suami informan. Menikah dini merupakan keinginan imforman dari dalam hati, tanpa ada paksaan dari pihak manapun.

Informan 3 adalah anak perempuan menikah pada usia 14 tahun, orangtua informan memperbolehkan informan menikah di usia muda dengan alasan suami informan yang sudah mapan. Latar belakang keluarga informan yang kebanyakan menikah di usia muda dulunya, membuat informan ingin menikah di usia muda seperti yang terjadi pada kerabat mereka, jawaban yang dilontarkan oleh informan ke 3 hampir sama dengan informan yang ke 2, yaitu keinginan informan menikah di usia muda karena adanya pengaruh dari pergaulan informan, kebanyakan teman-teman informan sudah menikah dini dan sudah mempunyai anak.

Informan 4 adalah anak laki yang berusia 17 tahun droup out MTs, yang bersangkutan termasuk pemuda mandiri dengan membuka lahan pertanian 
Kopi di daerahnya dan tidak bergantung kepada orang tuanya lagi. Informan ini menikah di usia muda atas kemamunya sendiri, dengan seorang gadis berstatus tunggu tubang yang rumahnya tidak berjauhan dengan tempat tinggalnya

Informan 5, adalah anak laki-laki 16 tahun, telah menamatkan SMP, yang bersangkutan dinikahkan oleh orang tuanya dengan seorang gadis berstatus tunggu tubang dan masih tergolong kerabat dekat.

Informan ke-6 adalah Kepala Desa dari salah satu desa yang diteliti, menurut informan ini terjadinya pernikah anak usia muda disebabkan beeberapa faktor: 1. Bahwa pihak kelaurga perempuan ingin cepat menikahkan anaknya agar ada yang membantu pekerjaan, karena sebagain besar tunggu tubang tersebut bermata pencaharian petani, 2. Ada perasaan tidak enak bahkan menjadi aib di tengah masyarakat kalau anak perempuan berstatus tunggu tubang lambat mendapatkan jodoh, 3. Pengaruh budaya, karena dari sejak dulu masyarakat semendo khususnya kelaurga tunggu tubang dinikahkan pada usia muda. 4. Anak yang berstatus tunggu tubang biasanya tidak disekolahkan lebih tinggi, dan memang sudah disiapkan untuk menjadi pengganti orang tua mengurus harta tunggu tubang. 5. Anak Perempuan tunggu tubang untuk mendapatkan calon suami biasanya dicarikan oleh keluarga terdekat perempuan

Informan ke-7 adalah tokoh masyarakat Kecmatan Semendo Darat Ulu, tokoh ini adalah seorang ulama yang disegani beliau adalah pengasuh salah satu pondok pesantren didaerah tersebut, pandangan beliau terhadap adanya pernikahan dini khusus untuk anak perempuan yang berstatus tunggu tubang pada prisnsipnya tidak bermasalah dengan agama, bahkan menurut informan ini justru mereka terhindar dari pergaulan bebas di era global saat ini, karena anak perempuan tersebut ditaarufkan, bahkan kebanyakan dilangsungkan perkawinan "gantung" yakni perjodohan yang direncanakan sejak awal tapi pelaksanaan ijab kabulnya ditunda beberapa tahun menunggu anak perempuan sudah siap untuk berkeluarga baik secara umur maupun dalam pergaulan kemasyarakatan. Bahkan setelah menikahpun jika dianggap pasangan yang sudah menikah belum sanggup mengatasi persoalan ekonomi dan hubungan dalam kekeluargaan dan masyarakat, tetap akan dibantu dan diawasi oleh kedua orang tua mereka secara bersama-sama. Didalam istilah adat disebut "ngasuh bunting".

Informan ke-8 adalah orang tua laki-laki dari anak perempuan berstatus tunggu tubang, menurut informan ini justru ia merasa senang kalau anak gadisnya yang masih berusia muda tersebut sudah banyak yang melamar untuk menjadikan istri anak gadisnya. Selanjutnya informan ini menjelaskan bahwa dia sudah terlalu lama mengurus harta tunggu tubang yang sangat ruwet tersebut, karena anak perempuan satu-satunya lahir terakhir. Dengan menikahkan anaknya maka status tunggu tubang tersebut akan beralih kepada anak perempuannnya, dan orang tua yang sudah menikahkan anak perempuan tunggu tubang sudah bisa hidup lebih santai dan bisa leluasa untuk berusaha lebih luas dan bisa juga merantau ketempat lain. Jadi menurut informan ini sebenarnya menjadi tunggu tubang itu memang banyak batasan-batasan dalam kehidupan dalam 
bermasyarakat khususnya dalam lingkungan keluarga besar tunggu tubang tersebut. Informan tersebut setelah mewariskan status tunggu tubang kepada anak perempuan dan menantunya, sekarang telah pergi perantau ke luar daerah untuk berkebun kopi yang lebih luas, karena masih banyak kewajiban yang harus dipersiapkan untuk membiayai anak-anak yang lainnya yang laki-laki dan masih ada yang kuliah di luar daerah. Informan ini mempunyai anak 5 orang.

Berdasarakan hasil wawancara yang dilakukan oleh peneliti terhadap ke 8 orang informan yakni 3 orang perempuan yang melangsungkan pernikahan dini dan berstatus tunggu tubang, 2 orang anak laki-laki yang menikah dengan anak perempuan berstatus tunggu tubang, serta kepada informan lain yakni, masingmasing 1 orang terhadap Kepala desa, 1 orang Tokoh masyarakat/Adat dan 1 orang tua (ayah) perempuan. Faktor utama terjadinya pernikahan dini bagi perempuan yang berstatus tunggu tubang adalah disebabkan keinginan keluarga besar terutama orang tua, kemudian faktor lain adalah masalah sosial yakni pengaruh adat dan ada juga karena masalah ekonomo walaupun tidak signifikan pada masyarakat Semendo yang berstatus tunggu tubang. Persoalan ekonomi dan sosial ini berdampak pada telah bergantinya status kepengurusan harta waris tunggu tubang maka orang tua tersebut bisa secara bebas berusaha mencari sumber kekayaan tanpa terbelenggu mengurus harta warisan tunggu tubang tersebut. Faktor lain bisa juga sebagai alasan untuk menjaga kehormatan anak perempuan untuk terimbas oleh pengaruh pergaulan bebas pada masyarakat semendo yang memegang teguh adat istiadat dan agama.

\section{Analisis}

Suku Semendo adalah masyarakat yang unik dalam pembagian harta waris, dimana anak perempuan tertua dijadikan sebagai pewaris tunggal harta tua yang sudah terjadi secara turun temurun yang disebut dengan harta "Tunggu Tubang". Oleh karena itu anak tertua perempuan yang akan menjadi pewaris tersebut seperti primadona desa yang akan menjadi perebutan oleh setiap orang untuk mendapatkan status sebagai anak yang dapat mempersunting anak gadis tunggu tubang. ${ }^{19}$ Anak perempuan yang berstatus tunggu tubang biasanya diawasi dengan ketat oleh kedua orang tua, bahkan oleh kerabat dekat anak tersebut, pergaulanya diperhatikan, dididik oleh orang tuanya untuk mengurus suatu keluarga, kebiasaan adat istiadat di tengah masyarakat selalu dilibatkan, dan biasanya diberikan pendidikan khusus pengetahuan keagamaannya ini juga berlaku bagi anak laki-laki yang akan dipersiapkan untuk dinikahkan dengan anak perempuan yang berstatus tunggu tubang. Sebagaimana keterangan Informan ke-4 dan ke-5 ( anak laki-laki) bahwa sejak ia menikah dengan anak tunggu tubang, maka ia harus merubah kebisaanya yang tidak baik, seperti persoalan ibadah, pekerjaan sehari-hari, pergaulan di tengah masyarakat harus benar-benar mencerminkan kebaikan,

${ }^{19}$ Yuni Sartika, Kadar Mahar...h. 9 
karena akan selalu diawasi oleh kedua-belah pihak keluarga. Apalagi dalam strata adat masyarakat semendo memang ada jabatan khusus dalam keluarga tersebut yang menjadi pengawas yakni disebut "Meraje".

Pada masyarakat Semendo status meraje ini mempunyai kekuasaan dan kewajiban yang cukup tinggi dalam strata keluarga sebagaimana penelitain Hasven Stamadova: "Meraje berkewajiban menegur dan memperingatkan, akan tetapi apabiila sudah diperingatkan masih juga melanggar aturan adat dan ajaran agama, maka meraje pula yang berkewajiban memberikan hukuman atau anksi sesuai dengan tingkat pelanggaran yang dilakukan". ${ }^{20}$

Bagi keluarga yang mempunyai anak laki-laki yang sudah pantas dinikahkan biasanya akan mencari gadis berstatus tunggu tubang, hal ini berlaku juga untuk keluarga perempuan dan biasanya "buyut Maraje" atau orang lain yang ditunjuk, yang akan mencarikan jika belum ada yang melamarnya. Hal ini bertujuan agar sataus keluarga tersebut terangkat dan mendapat kedudukan yang terhormat juga di tengah masyarakat, karena mampu untuk mempersunting anak gadis tunggu tubang, walaupun dengan biaya yang cukup besar untuk pernikahan adat pada masyarakat semendo. orang tua yang laki-laki yang bisa menikahkan anaknya kepada seorang gadis tunggu tubang akan terangkat derajatnya ditengah masyarakat, apalagi kalau anak laki-lakinya beberapa orang yang lain atau lebih dari satu orang anak lakilakinya yang dapat menyunting anak gadis tunggu tubang.

Akan tetapi dalam tulisan ini akan difokuskan pada pernikahan dini yang terjadi pada masyarakat semendo baik dalam kajian hukum positif, hukum Islam dan adat atau hukum adat, tidak akan membahas secara mendalam hal-hal yang berkaitan dengan masalah sosial dan ekonomi. Dalam penelitian ini juga akan dianalasisi hasil wawancara dengan informan sebagaimana disebutkan diatas, untuk itu dapat dikemukakan hal-hal sebagai berikut:

1. Pandangan Islam, hukum Positif dan Adat Semende dalam Pernikahan Dini

Batasan usia pernikahan dalam Islam ukuranya sudah Baligh sebagaiman disepakati oleh ulama fiqh. Sebagai batas usia yang menjadikan seseorang siap secara fisik untuk melaksanakan perkawinan, bagi laki-laki yang sudah keluar mani pada saat bermimpi dan perempuan yang sudah haid, hal demikian dipandang telah siap nikah secara biologis. Hukum menikahkan wanita yang belum sampai usia baligh (anak-anak) maka jumhur ulama termasuk para imam yang empat, bahkan ibnul Mundzir menganggapnya sebagai ijma adalah boleh

${ }^{20}$ Hasven Stamadova, Peranan Tokoh Adat dalam Mempertahankan Adat Tunggu Tubang pada Masyarakat Semendo di desa Sinar Semendo Kelurahan Labuhan Dalam Kecamatan Tanjung Senang Kota Bandar Lampung, Skripsi, Fakulats Pendidikan dan Kegurian, Uila, 2017, h. 36. 
menikahkan anak wanita yang masih kecil dengan yang sekufu' (sederajat/sepadan). ${ }^{21}$

Memang pernikahan bukan hanya berkaitan dengan biologis semata, lebih jauh dari itu pernikahan dalam pandangan Islam merupakan sunatullah yakni ibadah kepada Allah swt. oleh karena itu syarat lain disertakan dalam hukum perkawinan Islam seperti kesanggupan secara ekonomi, kematangan emosional dan kemampuan untuk saling tolong menolong dan saling melengkapi.

Di dalam UU No. 1 Tahun 1974 tentang Perkawinan dan Kompilasi Hukum Islam (KHI) telah disebutkan pembatasan umur usia pernikahan, namun dalam paraktiknya ketentuan hukum ini belum menjadi suatu acuan secara filosofis bagi umat Islam di Indonesia, hal ini dikarenakan umat Islam Indonesia sangat patuh pada aturan fikih dalam hal urusan perkawinan, sebagaimana dikatakan oleh Khairuddin Nasution bahwa "Sebab konsep yang berlaku secara umum dalam masyarakat muslim adalah konsep yang tertulis dalam kitab-kitab fiqh dan tafsir tradisional, khususnya mazhab syafi'i bagi masyarakat Indonesia. Akibatnya, konsep diluar kitab-kitab tersebut dianggap tidak sejalan dengan Islam (tidak Islami). ${ }^{22}$

Kemudian dalam UU No. 23 Tahun 2003 tentang Perlindungan Anak, Pasal 26 disebutkan bahwa orang tua berkewajiban untuk:

a. Mengasuh, memelihara, mendidik, dan melindungi anak;

b. Menumbuhkembangkan anak sesuai dengan kemampuan, bakat, dan minatnya; dan

c. Mencegah terjadinya perkawinan pada usia anak-anak.

Pada tataran praktiknya UU Perlindungan Anak, khususnya berkaitan dengan pencegahan terjadinya perkawinan pada usia anak dimana dalam UU tersebut yang dimaksud dengan anak adalah orang yang belum berusia 18 tahun, semakin sulit untuk diterapkan pada masyarakat muslim khususnya pada masyarakat muslim yang pengaruh adat istiadat yang masih kental seperti pada masyarakat Semendo.

Dalam masalah ekonomi untuk perkwainan tunggu tubang pada masyarakat semendo tidak menjadi persoalan, karena harta pusaka yang diwarisi tersebut lebih dari cukup untuk hidup dalam suatu keluarga baru pada masyarakat pedesaan. Disamping itu secara adat pada masyarakat semendo, keluarga yang baru menikah masih dibawah bimbingan kedua orang tuanya baik dari keluarga perempuan maupun dari keluarag laki-laki, termasuk dalam urusan ekonomi. Biasanya pada masyarakat semendo dalam mengurus harta

21 Azlan, Pernikahan Usia Dini Menurut Hukum Islam, Skripsi, Jurusan Perbandingan Hukum Dan Mazhab Fakultas Syariah Dan Ilmu Hukum Universitas Islam Negeri Sultan Syarif Kasim Pekanbaru Riau 2010, h.

10

${ }^{22}$ Khoiruddin Nasution, Status Wanita di Asia Tenggara; Studi Terhadap Perundangundangan Muslim Kontemporer di Indonesia dan Malaysia, Jakarta-Lieden: INIS, 2002, h. 274 
dan kebutuhan hidup sehari-hari tetap akan menjadi tanggung jawab orang tua kedua belah pihak sampai pasangan suami isteri yang menikah diusia muda tersebut sudah dianggap mampu oleh kedua orang tuanya baru diberikan kemandirian. Misalnya dalam urusan penggarapan sawah sebagai harta pokok pada tahun pertama pihak keluarga laki-laki akan membantu pekerjaannya termasuk membawa bantuan kebutuhan tambahan sehari-hari seperti sayuran, gula kopi dan sebagainya, ini sebagai tanda bahwa keluarga laki-laki mempunyai kemampuan secara financial. Sebagaiman disebutkan diatas bahwa untuk menikahkan anak laki-laki kepada anak perempuan memang membutuhkan biaya yang cukup besar. Berdasarkan penjelasan Informan ke-7 (orang tua anak perempuan), bahwa pihak laki-laki yang melamar anaknya dengan kesepakatan sesuai dengan adat istiadat, yakni akan diadakan upacara adat dengan memotong seekor Kerbau (untuk sekarang sudah bisa diganti dengan seekor sapi), ditambah dengan perlengkapan rumah tangga selengkapnya seperti: Lemari besar dan Kecil, Kursi Tamu, Tempat Tidur lengakap dengan peralatannya, peralatan masak, mesin jahit dan lain-lain, pihak perempuan juga mengeluarkan biaya untuk jamuan dan hiburan. Informan 6 (Kepala Desa) menyebutkan perkiraan biaya untuk pernikahan anak tunggu tubang yang harus disipakan oleh pihak laki-laki untuk saat ini bisa mencapai Rp. 100.000.000,- sampai Rp. 200.000.000,- ini suatu biaya pernikahan yang cukup tinggi untuk masyarakat pedesaan, namun faktanya adat ini tetap berlangsung sampai dengan sekarang.

Kekhawatiran para pakar terhadap dampak dari pernikahan dini dari berbagai analisis di Indonesi masih menjadi problem utama dalam seluruh rangaian dari dampak sebuah perkawinan, data-data statistik maupun kajiankajian para pakar menunjukan bahwa banyaknya kasus perceraian yang diawali dari Kekerasan dalam rumah tangga (KDRT), berdasarkan data Bappenas tahun 2008 akibat pernikahan dini terdapat 690.000 kasus perceraian..$^{23}$ Secara ekstrim ada yang mengatakan bahwa pernikahan dini merupakan pelanggaran terhadap HAM, serta melanggar ketentuan hukum positif.

Statmen tersebut jika dianalisis berdasarkan tabel 2 diatas, berbanding terbalik dengan fakta untuk masyarakat suku semendo, hasil penelitian menunjukan masih tingginya angka pernikahan dini pada masyarakat tersebut, tetapi tidak pernah terjadi perceraian ekses dari pernikahan dini termasuk adanya KDRT. Sebagaimana telah ditulis diatas bahwa perkawinan pada masyarakat Semende khususnya bagi perempuan yang berstatus tunggu tubang merupakan peristiwa adat yang luar biasa sakralnya.

2. Pembagian Waris dalam Pandangan Hukum Islam dan Adat Semende

23 Dwi Rifiani, Pernikahan Dini Dalam Perspektif Hukum Islam, https://www.researchgate.net, diakses, 3 Juni 2019. 
Sebagaimana data pada tabel 3 bahwa penduduk Kecamatan Semendo darat Ulu $100 \%$ beragama Islam, ${ }^{24}$ aka tetapi dalam kontek pembagian waris berbeda dengan konsep hukum waris Islam. Waris dalam hukum Islam diatur secara rigit syarat dan rukunya, baik terhadap harta yang diwariskan ( $\mathrm{Al}$ Mauruts) maupun terhadap pewaris (Al-Muwarris) dan penerima warisan ( $\mathrm{Al}$ warits). Dengan bersumber pada hukum Islam maka pembagian warisan, sebagaiman termuat dalam Al Qur'an antara lain surat An-Nisa ayat 11 yang dapat disimpulkan bahwa "Allah sudah mensyariatkan tentang pembagian harta waris/pusaka yaitu bagian seorang laki-laki sama dengan bagian bagian dua orang anak perempuan dan jika anak itu semuanya perempuan lebih dari dua, maka bagi mereka memperoleh 2/3 dari harta yag ditinggalkan, jika perempuan sorang saja maka memperoleh separo harta. Sesungguhnya Allah maha mengetahui dan maha bijaksana".

Berdasarkan penjelasan diatas maka dalam kewarisan hukum Islam tidak mengenal dengan adanya pemutusan atau peralihan harta waris karna dalam hukum Islam sudah dijelaskan bagian-bagian dari masing masing ahli warisnya.

Sebagaimana diketahui bahwa anak tunggu tubang tersebut adalah anak perempuan pewaris tunggal harta pusaka secara turun-temurun. Padahal di dalam hukum Islam (kumpulan fikih-fikih), disebutkan maksimal 2/3 tetapi untuk masyarakat semendo hal itu tidak berlaku. Sebagaimana penelitian Mukhlis dan kawan-kawan yang menyebutkan bahwa:

Hukum adat waris memuat peraturan-peraturan yang mengatur proses meneruskan serta mengalihkan barang-barang harta benda dan barang-barang yang tidak berwujud benda (immateriil gaederen) dari suatu generasi manusia (generatie) kepada turunannya. Proses tersebut mulai pada waktu orang tua kepada turunannya. Sepeti hasil penelitian di atas yang menunjukan hahwa masyarakat adat Semendo ini memiliki sistem kewarisan mayorat, dimana penguasaan tunggal atas harta peninggalan ditangan anak tertua perempuan. ${ }^{25}$

Hukum waris adat ialah peraturan-peraturan yang mengatur proses meneruskan serta pengoperkan barang barang yang berujud harta benda atau yang tidak berujud benda dari suatu angkatan manusia kepada keturunannya. Meninggalnya orang tua memang merupakan suatu peristiwa penting bagi proses pewarisan, akan tetapi tidak mempengaruhi secara radikal proses penerusan dan pengoperan harta benda dan hak atas harta benda tersebut. ${ }^{26}$

Mengenai pembagian waris yang menyimpang dari hukum Islam tersebut informan ke-5 sebagai tokoh agama sekaligus tokoh masyarakat yang

24 Adetia Prasetiawan, Profil Semende People, https://www.academia.edu, diakses, 3 Juni 2013.

${ }_{25}$ Mukhlishin, A., dkk. Studi Hukum Islam Terhadap Kewarisan Masyarakat Adat Semendo Kabupaten Lampung Barat Di Era Kontemporer Ulul Albab Volume 18, No.1 Tahun 2017

${ }^{26}$ Otje Salman, Kesadaran Hukum Masyarakat Terhadap Hukum waris, Bandung: PT Alumni, 2007, h. 32 
menjadi panutan di daerah tersebut mengatakan, ${ }^{27}$ bahwa sistem kewarisan yang berlaku pada masyarakat semendo tidak didasarkan pada perhitungan pembagian waris secara Islam, walaupun masyarakatnya sangat taat menjalankan perintah agama. Tetapi berdasarkan adat leluhur dengan filosofi bahwa perempuan adalah tumpuan kehidupan dalam berbagai aspek, oleh karena itu menurut informan ini adalah wajar jika perempuan diberikan hak istimewa dalam pengelolaan harta peninggalan nenek moyang sebagai pemegang waris tunggal. Selanjutnya informan ini menjelaskan bahwa sifat dari harta warisan yang jatuh ke pada anak tertua tersebut hanyalah sebatas menjaga dan mengusahakannya, tidak boleh dijual atau dialihkan kepada orang lain.

Warisan semacam ini dalam masyarakat semende sangat dihormati dan dijunjung tinggi sebagi simbol dari kekerabatan tunggu tubang, sebagaiman dikemukakan oleh Fauzi: "Dengan tradisi tunggu tubang yang mereka anut, dalam ensiklopedi tersebut masyarakat Semendo dikategorikan sebagai salah satu penganut prinsip kekerabatan matrilineal, sebagaimana masyarakat Minangkabau. "Sesuai dengan tradisi tunggu tubang, anak perempuan paling tua menjadi pemegang hak warisan keluarga. warisan berupa rumah dan sawah itu tidak boleh dijual". ${ }^{28}$

Dalam hukum positif hakum waris Islam didasarkan Pada Instruksi Presiden Nomor 1 Tahun 1981 Tentang Kompilasi Hukum Islam. KHI merupakan salah satu bentuk Ijtihad para ulama dalam menentukan Hukum waris Islam sebagai hukum positif di Indonesia. ${ }^{29}$

Pasal 172 KHI menyatakan bahwa ahli waris dipandang beragama Islam apabila diketahui dari kartu identitas atau pengakuan atau amalan atau kesaksian. Sedangkan bagi bayi yang baru lahir yang belum dewasa, agama biasanya mengikuti keyakinan yang dianut ayahnya dan lingkungannya. ${ }^{30}$

Menurut pandangan fikih, hukum adat dapat dijadikan sebagai sumber hukum yang dikenal dengan istilah "urf" yakni Secara etimologi 'urf berarti "sesuatu yang dipandang baik dan diterima oleh akal sehat"

Oleh karena itu untuk menganalisis waris tunggu tubang ini harus dilihat bahwa harta tunggu tubang tersebut sebenarnya tidak dibagi hanya dipindahkan penguasannya kepada anak perempuan tertua dengan cara demikian masyarakat semendo dalam kekeluargaannya tetap terjadi keharmonisan sehinggal adat ini masih bisa bertahan sampai sekarang hal ini didasarkan kepada pandangan bahwa: "adat tunggu tubang dapat dikatagorikan sebagai Al-'urf al-shokhih, yaitu kebiasaan yang berlaku ditengah-tengah masyarakat yang tidak

27 Wawancara, tanggal 24 Februari 2019.

${ }^{28}$ Mohammad Yasir Fauzi, Sistem Kewarisan Adat Semende dalam Tinjauan Hukum Islam, https://media.neliti.com, diakses 22 Mei 2019.

29 Abdurahman, Kompilasi Hukum Islam di Indonesia, Cetakan ke III, Jakarta : Akademika Pressindo hlm. 12.

${ }^{30}$ Direktorat Jendral Bimbingan Masyarakat Islam Departemen Agama Republik Indonesia, Himpunan Perundang-Undangan Perkawinan, 2009, h. 276.

${ }^{31}$ Efendi Satria dan Zein. Ushul Fiqih. Jakarta: Pernada Media. 2005, h:153 
ADHKI: Journal of Islamic Family Law

bertentangan nash (ayat atau hadist), tidak menghilangkan kemaslahatan mereka, dan tidak pula membawa mudarat kepada mereka".32

\section{Kesimpulan}

Berdasarkan data dan analisis di atas maka penulis menyimpulkan halhal sebagai berikut:

1. Pada masyarakat Semendo masih memegang adat-istiadat dimana praktik pernikahan dini dianggab hal yang biasa.

2. Motif adanya pernikahan dini pada masyarakat semendo adalah untuk mengalihkan tanggunggung jawab dalam pengurusan harta waris tunggu tubang.

3. Masyarakat semendo yang penduduknya $100 \%$ beragama Islam yang taat, dalam masalah pernikahan lebih mengutamakan hukum Islam dari hukum positif.

4. Pada masyarakat semendo hampir tidak ada dampak negatif yang terjadi dari ekses adanya pernikahan dini.

\section{Daftar Pustaka}

Buku dan Jurnal

Abdurahman, 2014, Kompilasi Hukum Islam di Indonesia, Cetakan ke III, Jakarta: Akademika Pressindo.

Azlan, 2010, Pernikahan Usia Dini Menurut Hukum Islam, Skripsi, Jurusan Perbandingan Hukum Dan Mazhab Fakultas Syariah Dan Ilmu Hukum Universitas Islam Negeri Sultan Syarif Kasim Pekanbaru Riau 2010.

Beteq Sardi, 2016, Faktor-faktor Pendorong Pernikahan Dini dan Dampaknya Di Desamahak Baru Kecamatan Sungai Boh Kabupaten Malinau, Journal, SosiatriSosiologi 2016, 4(3): 194-207ISSN 0000-0000.

Direktorat Jendral Bimbingan Masyarakat Islam Departemen Agama Republik Indonesia, Himpunan Perundang-Undangan Perkawinan, 2009.

Hasven Stamadova, 2017, Peranan Tokoh Adat dalam Mempertahankan Adat Tunggu

Tubang pada Masyarakat Semendo di desa Sinar Semendo Kelurahan Labuhan

Dalam Kecamatan Tanjung Senang Kota Bandar Lampung, Skripsi, Fakulats

Pendidikan dan Kegurian, Uila, 2017, h. 36

Imam Mahdi, 2019, Konsep Gender Pada Masyarakat Adat Suku Semendo Kabupaten Muara Enim: Studi Kasus Pada Adat "Tunggu Tubang", Jurnal Hawa SPG IAIN Bengkulu Tahun 2019.

Iskandar, 2003, Kedudukan anak "Tunggu Tubang" dalam Kewarisan Masyarakat Adat Suku Semendo di Kota Palembang, Tesis Program Kenotaritan Universitas Diponegoro. Semarang, 2003.

${ }^{32}$ Mohammad Yasir Fauzi, Sistem Kewarisan....Op. Cit 
Juspin Landung, 2003, Studi Kasus Kebiasaan Pernikahan Usia Dini Pada Masyarakat Kecamatan Sanggalangi Kabupaten Tana Toraa, Jurnal MKMI, Vol 5 No. 4, Oktober 2003

Khoiruddin Nasution, 2002, Status Wanita di Asia Tenggara; Studi Terhadap Perundang-undangan Muslim Kontemporer di Indonesia dan Malaysia, JakartaLieden: INIS, 2002.

Mukhlishin, A., dkk. 2017, Studi Hukum Islam Terhadap Kewarisan Masyarakat Adat Semendo Kabupaten Lampung Barat Di Era Kontemporer Ulul Albab Volume 18, No.1 Tahun 2017

Otje Salman, 2007, Kesadaran Hukum Masyarakat Terhadap Hukum waris, Bandung: PT Alumni, 2007.

Satria Efendi dan Zein. 2005, Ushul Fiqih. Jakarta: Pernada Media. 2005.

Sunarto, 2007. Bahan Penyuluhan BKR Tentang Materi Ketahanan Keluarga Bagi Calon Pengantin. Jakarta: Badan Kependdudukan dan Keluarga Berencana Nasional (BkkbN).

Syarifah Salmah, 2016, Pernikahan Dini Ditinjau Dari Sudut Pandang Sosial Dan Pendidikan, Alhiwar Jurnal Ilmu dan Teknik Dakwah Vol. 04 No. 07 Januari-Juni 2016.

Yenrizal dkk. 2015, Makna Simbolik Sawah di Masyarakat Pedesaan Tinjauan Komunikasi Lingkungan pada Masyarakat Semende Darat Tengah, Jurnal Kawistara, Vol. 5, No. 3, Desember 2015

Yuni Sartika, 2015, Kadar Mahar Perkawinan Terhadap Anak Tunggu Tubang Di Kecamatan Semende Darat Kabupaten Muara Enim Ditinjau Dari Mazhab Syafi'i Dan Mazhab Hanafi, Skripsi, Fakultas Syari'ah UIN Raden Fatah Palembang, 2015.

Media Cetak dan On Line

Adetia Prasetiawan, Profil Semende People, https://www.academia.edu.

Mohammad Yasir Fauzi, Sistem Kewarisan Adat Semende dalam Tinjauan Hukum Islam, https://media.neliti.com, diakses 22 Mei 2019

Eddy Fadlyana, Shinta Larasaty, Penikahan dini dan Permasalahannya, https://www.researchgate.net

Dian Kartikasari, Penyebab Pernikahan Anak Karena Kemiskinan Dan PendidikanRendah, https://news.detik.com. Diakses 27 Mei 2019.

Dwi Rifiani, Pernikahan Dini Dalam Perspektif Hukum Islam, https://www.researchgate.net, diakses, 3 Juni 2019.

Lies Marcoes, Kemiskinan Struktural Adalah Faktor Terbesar Penyebab Praktek Perkawinan Anak, https://www.voaindonesia.com, diakses 28 Mei 2019.

https://news.detik.com/kolom/d-4044812/indonesia-masih-darurat-perkawinananak.

https://muaraenimkab.bps.go.id.

Badan Pusat Statistik 2010, https://www.bps.go.id

http://biofarmaka.ipb.ac.id 